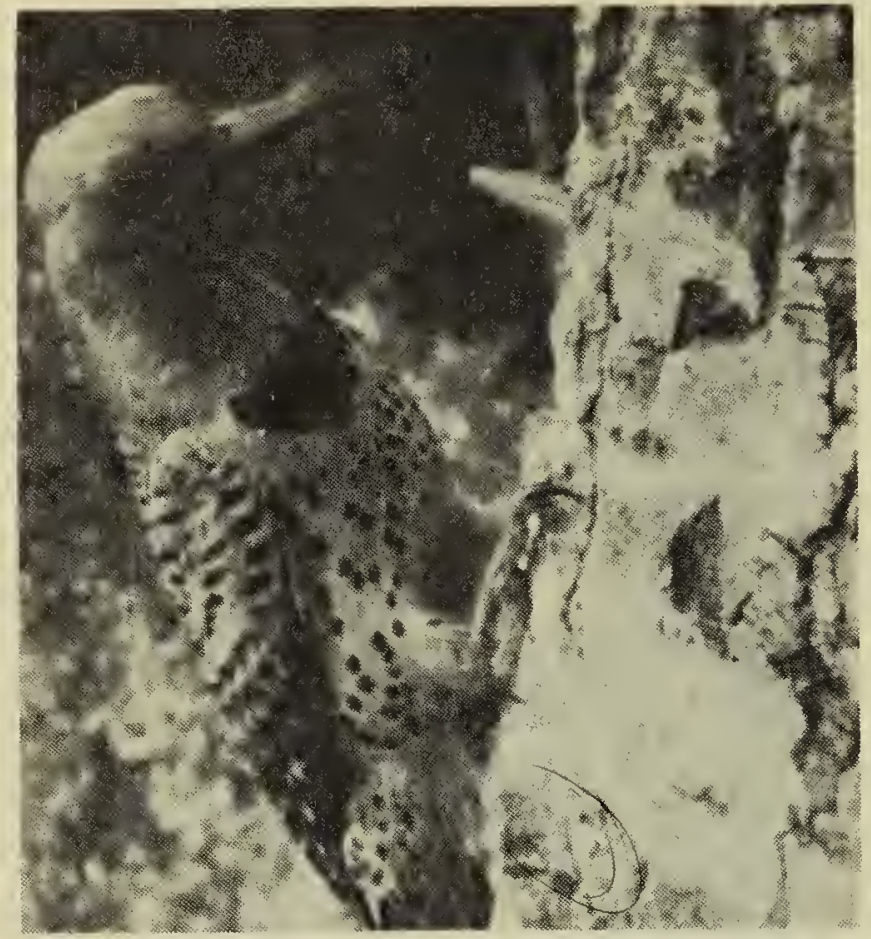

Flicker at Nesting Hole

charm with me that I shall not soon forget.

I took the picture by remote control with a Portra 2 lens at 19 inches. at $\mathrm{f} / 11$ and speed at $1 / 100$ of a second.

\section{My Little Nature World}

Madeline B. Runyan, Punnichy, Sask.

During the summer of 1953 I found a poor bird breathing its last under my clothesline. Evidently the unfortunate little thing had flown into the wire. It was an entirely new bird to me-and I have lived here all my life. Not having Peterson's Field Guide (I now have one), I did not identify it closely enough, but it was either an Olive-backed Thrush, or a Gray - checked Thrush. Peterson shows that there is a very slight difference between them, of which I was not aware at the time.

During the very severe weather of the past January, we found a tiny owl which had perished in the straw stack. I suppose even the mice were not out in such weather. The little owl measures only $6 \frac{1}{2}$ inches from beak to tail. Because of its black bill and other markings, we have identified it as a Saw-Whet Owl.

Our lunch counter in an elm near our kitchen window is constantly visited by the little Chickadees, who have to move off whenever the Downy Woodpecker arrives. $\mathrm{He}$, in turn, makes himself scarce, when his big cousin, the Hairy Woodpecker comes.

\section{A Survey of Birds Nesting in a Given Area}

By E. H. Brooman, Prince Albert

This survey grew out of a class discussion on environment and adaptation. At the time we had been discussing the fact that some birds and animals favor environments near man while others prefer environments as far removed from man as possible.

It was decided to attempt to discover how many and what kind of birds nested in our own-school district.

The Prince Edward School district is composed of some forty city blocks. Most of this is residential and there are few vacant areas. In addition to this there is an unimproved area which for the most part is cleared.

In much of the district the boulevard is well established. In some sections the trees are several decades old. Many of the homes are reasonably well landscaped. All-in-all, the district is excellent for this type of survey.

The purpose, then, was to make a count of all visible birds' nests. Only nests which could be seen from the sidewalk area were included. Each student was supplied with a mimeographed sheet and allotted a certain area to survey. So that there would be a minimum of errors, instructions were simplified and few.

The survey showed:

Total number of nests, 189.

Total in Boulevards, 64; those high, 24: medium. 35; low, 5 .

Private Trees and Shrubs, 92; those high 30 ; medium, 34; low, 28.

Total in Hedges, 20. Others, 13.

It should be noted that no consideration was given to birds nesting in boxes nor was any consideration given to areas other than adjacent to sidewalks.

Considering the number of nests that had probably been destroyed we see that the bird population would be considerable. Assuming three young were raised in each nest, and two adult birds attended each nest, we would have a population of almost 1000 birds. Indeed, it is quite possible that there were at least twice this number. 